\title{
Service Delivery Location
}

National Cancer Institute

\section{Source}

National Cancer Institute. Service Delivery Location. NCI Thesaurus. Code C95335.

A physical place at which services are provided. 